\title{
Optimalisasi Pemanfaatan dan Profesionalisme Pengelolaan Aset Desa dalam Meningkatkan Pendapatan Asli Desa
}

\author{
Putu Eka Dianita Marvilianti Dewia, ${ }^{*}$, Komang Adi Kurniawan \\ Saputrab $^{\mathrm{b}}$ Made Aristia Prayudic \\ a,c Universitas Pendidikan Ganesha, Jalan Udayana No. 11, Singaraja, \\ Indonesia \\ *(ekadyanita@gmail.com) \\ bUniversitas Warmadewa, Jl. Terompong No.24, Sumerta Kelod, Denpasar \\ Tim., Kota Denpasar, Bali, Indonesia
}

\begin{abstract}
ABSTRAK
Penelitian ini mengangkat topik pengelolaan aset desa pada desa-desa di Provinsi Bali sebab kasus-kasus penyalahgunaan aset desa oleh aparat pemerintah desa telah menjadi problematika yang marak terjadi pada desa-desa di wilayah Provinsi Bali. Tujuan utama penelitian ini adalah untuk menginvestigasi pengaruh optimalisasi pemanfaatan aset desa dan profesionalisme pengelolaan aset desa terhadap peningkatan pendapatan asli desa. Data dikumpulkan melalui penyebaran kuesioner kepada 87 kepala desa dan sekretaris desa di wilayah Kabupaten Buleleng, kabupaten terbesar di Provinsi Bali. Data selanjutnya dianalisis secara kuantittatif menggunakan teknik regresi linier berganda. Hasil penelitian menunjukkan bahwa upayaupaya optimalisasi dan profesionalisme pengelolaan aset desa secara signifikan berpengaruh positif terhadap peningkatan pendapatan asli desa.
\end{abstract}

Kata kunci: optimalisasi pemanfaatan aset desa, profesionalisme pengelolaan aset desa, pendapatan asli desa, Kabupaten Buleleng Provinsi Bali

\begin{abstract}
This study addresses the issue of village assets management in Bali Province of Indonesia since the cases of misuse and abuse of village assets by village apparatuses became a frequent problem in the Bali Province. The main objective of this study was to investigate the effect of optimization of village assets utilization and professionalism of village assets management on the improvement of village original revenues. The data were collected through self-administered questionnaires distributed to 87 village heads and village secretaries in Buleleng Regency, the largest district of Bali Province. Data analysis was performed using multiple linier regression technique. This study found that the efforts of optimizing the utilization and professionalism of village assets management significantly have positive impact on the improvement of village original revenue.

Keywords: optimization of village assets utilization, professionalism of village assets management, village original revenues, Buleleng Regency of Bali Province
\end{abstract}


Dewi, Saputra, Prayudi - Optimalisasi Pemanfaatan dan Profesionalisme Pengelolaan ...

\section{PENDAHULUAN}

Undang-undang Desa No. 6 tahun 2014 membawa terobosan baru bagi Pemerintahan Desa dan masyarakat desa dalam membangun serta meningkatkan kesejahteraan ekonomi masyarakat desa. Salah satu program yang dapat dilakukan sesuai dengan amanat UU desa tersebut adalah melalui pengelolaan aset desa. Aset desa merupakan aset milik desa yang digunakan sebaik-baiknya untuk kemajuan dan kemakmuran masyarakat desa. Namun, dalam implementasinya terkadang tidak sesuai dengan maksud dan tujuan tersebut.

Berdasarkan Undang-undang Republik Indonesia Nomor 6 Tahun 2014 tentang Desa bahwa aset desa adalah barang milik desa yang berasal dari kekayaan asli desa, dibeli atau diperoleh atas beban Anggaran Pendapatan dan Belanja Desa atau perolehan hak lainnya yang sah. Aset desa dapat berupa tanah kas desa, tanah ulayat, pasar desa, pasar hewan, tambatan perahu, bangunan desa, pelelangan ikan, pelelangan hasil pertanian, hutan milik desa, mata air milik desa, pemandian umum, dan aset lainnya milik desa. Selanjutnya aset ini dapat dikelola dengan baik untuk dapat meningkatkan pendapatan asli desa sehingga mampu meningkatkan perekonomian di desa dan menuju desa yang mandiri. Untuk mencapai pemanfaatan aset yang optimal diperlukan pengelolaan atas siklus hidup aset tersebut. Mengingat pentingnya pengelolaan aset milik desa, maka sudah menjadi keharusan bagi pemerintah desa untuk melakukan pengelolaan aset milik desa secara professional, efektif dan mengedepankan aspek ekonomi supaya dalam pemanfaatan aset desa dapat tercapai kesejahteraan ekonomi masyarakat desa.

Beberapa desa di Bali menghadapi beberapa permasalahan terkait dengan pemanfaat aset desa dan pengelolaannya, hal tersebut misalnya di beberapa desa masih belum jelas sumber keuangan yang diberikan pada pemanfaatan aset desa dan belum optimalnya fungsi BPD (Badan Permusyawaratan Desa) yang bekerjasama dengan Kepala Desa menyusun peraturan desa dalam pemanfaatan dan pengelolaan aset desa. Hal tersebut tercantum dalam UU No.6 tahun 2014 dalam pasal 77 ayat 3 yang isinya adalah Pengelolaan kekayaan milik Desa dibahas oleh Kepala Desa bersama Badan Permusyawaratan Desa berdasarkan tata cara pengelolaan kekayaan milik Desa yang diatur dalam Peraturan Pemerintah. 


$\begin{array}{rcr}\text { Masalah } & \text { ini } & \text { menjadi } \\ \text { problematika } & \text { yang } & \text { harus }\end{array}$

terselesaikan sehingga harapan untuk menjadi desa yang maju dan mandiri dapat tercapai. Perwujudan pemanfaatan aset desa dalam hal ini dalam bentuk BUMDesa, badan usaha ini nantinya akan dikelola oleh Pemerintah Desa, pengelolaan kekayaan desa harus berdayaguna dan berhasil guna untuk meningkatkan pendapatan desa. Permasalahan seperti ini jika tetap dibiarkan akan berpotensi pada penyalahgunaan aset desa oleh oknum pemerintahan desa atau yang berpengaruh di desa. Seperti yang terjadi pada kasus penyalahgunaan aset Pemprov Bali di Kabupaten Gianyar pada bulan Januari tahun 2015, dimana pada kasus tersebut terjadi pemalsuan tanda tangan Bupati untuk sewa aset/tanah milik Pemprov Bali di Gianyar yang dilakukan oleh oknum di Pemerintahan Daerah (Bali Post, 11 Januari 2015). Hal ini dapat terjadi pada kapasitas yang lebih kecil yaitu di desa.

Konflik yang lain di desa sering terjadi terutama dalam pendirian BUMDesa, seperti yang terjadi di kawasan wisata goa pindul, Desa Bejiharjo, Karangmojo Jogjakarta. Konflik ini terjadi karena ada keinginan pendirian BUMDesa oleh
Pemerintahan Desa setempat namun ditolak oleh kelompok wisata karena sejak 2012 telah dikelola oleh kelompok wisata secara swadaya, dan sampai saat ini telah mengalami peningkatan (HarianJogja.com, 10 September 2016). Namun, beberapa keberhasilan BUMDesa juga telah banyak dinikmati masyarakat desa, diantaranya seperti yang terjadi di Bali yaitu adanya rumah makan herbal serba beras merah di Lovina Singaraja, BUMDesa Giri Amerta di Desa Alasangker Kecamatan Buleleng, BUMDesa Pandan Harum Desa Selat Kecamatan Sukasada yang mengelola hutan Buleleng, serta BUMDesa lainnya di desa-desa yang ada di Bali khususnya di Kabupaten Buleleng sebagai obyek penelitian ini.

Dilihat dari segala konflik dan juga beberapa keberhasilan pengelolaan keuangan desa dan asset desa dalam bentuk BUMDesa maka sangat perlu untuk dimanfaatkan secara optimal dan dikelola dengan professional sehingga manfaatnya dapat dirasakan oleh masyarakat desa. Berdasarkan hal tersebut maka penelitian ini berjudul "Optimalisasi Pemanfaatan dan Profesionalisme Pengelolaan Aset Desa dalam Meningkatkan Pendapatan Asli Desa” dengan mengambil obyek penelitian di Kabupaten Buleleng karena memiliki jumlah desa yang menerima dana 
desa salah satu tertinggi di Bali dan merupakan wilayah terluas di Pulau Bali sehingga berpotensi memiliki aset desa yang luas dan berpotensi memiliki bervariasi jenis usaha BUMDesa. Secara umum, penelitian ini ingin menjawab tiga pertanyaan berikut: 1) Apakah optimalisasi pemanfaatan aset berpengaruh terhadap pendapatan asli desa?; 2) Apakah profesionalisme pengelolaan aset berpengaruh terhadap pendapatan desa?; dan 3) Apakah optimalisasi pemanfaatan aset dan profesionalisme pengelolaan aset berpengaruh secara simultan terhadap pendapatan asli desa?

\section{TELAAH LITERATUR DAN PERUMUSAN HIPOTESIS}

Pendapatan Asli Desa

Alokasi Dana Desa yang memadai untuk menunjang sumber penerimaan APBDesa, diharapkan akan mampu mendorong roda pemerintahan di tingkat desa, termasuk untuk menanggapi kebutuhan-kebutuhan yang mampu ditangani di tingkat desa. APBDesa yang memadai juga dapat mendorong partisipasi warga lebih luas pada proses-proses perencanaan dan penganggaran pembangunan. Partisipasi warga yang tidak terakomodasi dalam APBD, dengan adanya APBDesa dapat menjawab partisipasi warga yang bersifat mikro dan mampu ditangani pada level desa. Supaya Alokasi Dana Desa dalam pelaksanan APBDesa benarbenar diimplementasikan, perlu dilakukan proses penguatan Pemerintahan Desa (Pemerintah Desa dan Badan Permusyawaratan Desa) dalam mengelola keuangan desa, khususnya peningkatan Pendapatan Asli Desa (PADes) yang berorientasi kepada peningkatan kesejahetraan masyarakat desa dan memenuhi prinsip-prinsip good governance.

Penyediaan sumber - sumber pendapatan asli desa yang berhasil guna dan tepat guna selama ini tidak pernah memperhitungkan potensi yang sesungguhnya. Pada umumnya dan kebiasaan selama ini perhitungan lebih mengandalkan pada target dan realisasi yang ada. Dengan demikian ke depan, Desa diharapkan mampu menggali sumber-sumber pendapatan desa seoptimal mungkin yang bersumber dari potensi yang ada di masing-masing desa.

Pendapatan asli desa (PAD) merupakan segala usaha yang dilakukan oleh pemerintah desa untuk menunjang penyelenggaraan pemerintahan desa dalam rangka pelaksanaan otonomi desa. Secara lebih khusus disebutkan bahwa PAD terdiri dari hasil usaha desa, hasil kekayaan desa, hasil swadaya dan 
partisipasi, hasil gotong royong, dan lain-lain pendapatan asli desa yang sah (Undang-undang Nomor 6 Tahun 2014 tentang Desa).

\section{Aset Desa}

Sesuai ketentuan umum, disebutkan bahwa Aset Desa adalah barang milik Desa yang berasal dari kekayaan asli Desa, dibeli atau diperoleh atas beban Anggaran Pendapatan dan Belanja Desa atau perolehan hak lainnya yang sah. Pasal 76 Undang-undang Nomor 6 Tahun 2014 tentang Desa menyebutkan bahwa Aset Desa dapat berupa tanah kas Desa, tanah ulayat, pasar Desa, pasar hewan, tambatan perahu, bangunan Desa, pelelangan ikan, pelelangan hasil pertanian, hutan milik Desa, mata air milik Desa, pemandian umum, dan aset lainnya milik Desa.

Aset Desa dapat berupa tanah kas Desa, tanah ulayat, pasar Desa, pasar hewan, tambatan perahu, bangunan Desa, pelelangan ikan, pelelangan hasil pertanian, hutan milik Desa, mata air milik Desa, pemandian umum, dan aset lainnya milik Desa. Aset lainnya milik Desa sebagaimana dimaksud pada ayat (1) antara lain: (a) kekayaan Desa yang dibeli atau diperoleh atas beban Anggaran Pendapatan dan Belanja Negara, Anggaran Pendapatan dan
Belanja Daerah, serta Anggaran Pendapatan dan Belanja Desa; (b) kekayaan Desa yang diperoleh dari hibah dan sumbangan atau yang sejenis; (c) kekayaan Desa yang diperoleh sebagai pelaksanaan dari perjanjian/kontrak dan lain-lain sesuai dengan ketentuan peraturan perundang-undangan; (d) hasil kerja sama Desa; dan (e) kekayaan Desa yang berasal dari perolehan lainnya yang sah.

Aset desa lainnya yang terkandung dalam Undang-undang Nomor 6 Tahun 2014 tentang Desa, yaitu kekayaan milik Pemerintah dan Pemerintah Daerah berskala lokal Desa yang ada di Desa dapat dihibahkan kepemilikannya kepada Desa, kekayaan milik Desa yang berupa tanah disertifikatkan atas nama Pemerintah Desa, kekayaan milik Desa yang telah diambil alih oleh Pemerintah Daerah Kabupaten/Kota dikembalikan kepada Desa, kecuali yang sudah digunakan untuk fasilitas umum, dan bangunan milik Desa harus dilengkapi dengan bukti status kepemilikan dan ditatausahakan secara tertib.

\section{Optimalisasi Pemanfaatan Aset Desa} Pengelolaan Aset Desa merupakan rangkaian kegiatan mulai dari perencanaan, pengadaan, 
Dewi, Saputra, Prayudi - Optimalisasi Pemanfaatan dan Profesionalisme Pengelolaan ...

penggunaan,

pemanfaatan,

pengamanan,

pemeliharaan,

penghapusan, pemindahtanganan, penatausahaan, pelaporan, penilaian, pembinaan, pengawasan dan pengendalian aset Desa (Permendagri No. 1 Tahun 2016 tentang Pengelolaan Aset Desa). Pengelolaan aset Desa dipimpin oleh Kepala Desa dan dibantu Sekretaris Desa (pasal 4 dan 5 Pengelolaan Aset Desa). Dan Aset Desa yang berupa tanah ketika dipinjamsewakan harus mendapat ijin tertulis dari Bupati.

Pengelolaan asset desa dapat secara optimal dilakukan salah satunya dengan mendirikan BUMDesa. Desa dapat mendirikan Badan Usaha Milik Desa yang disebut BUMDesa. BUMDesa dikelola dengan semangat kekeluargaan dan kegotongroyongan. BUMDesa dapat menjalankan usaha di bidang ekonomi dan/atau pelayanan umum sesuai dengan ketentuan peraturan perundang-undangan (UU No.6 Tahun 2014 tentang Desa).

Profesionalisme Pengelolaan Aset

Profesionalisme di sini lebih ditujukan kepada kemampuan aparatur dalam memberikan pelayanan yang baik, adil, dan inklusif serta tidak hanya sekedar kecocokan keahlian dengan tempat penugasan. Sehingga aparatur dituntut untuk memiliki kemampuan dan keahlian untuk memahami dan menterjemahkan aspirasi dan kebutuhan masyarakat ke dalam kegiatan dan program pelayanan (Riyanto, 2014). Dalam hal ini, profesionalisme aparatur desa sepenuhnya dapat mengklasifikasikan program pengelolaan aset desa agar lebih mudah dalam hal pengelolaan dan juga pengawasan. Pengelolaan Pendapatan Asli Desa (PAD) dilakukan berasaskan prinsip transparan, akuntabel, partisipatif, serta tertib dan disiplin dikaji dari perencanaan, penganggaran, penatausahaan, pelaporan, pertanggungjawaban sampai pengawasan (Astuti, 2015).

Menurut Sedarmayanti (2013) profesionalisme adalah pilar yang akan menempatkan birokrasi sebagai mesin yang efektif bagi pemerintah dan sebagai parameter kecakapan aparatur dalam bekerja secara baik. Ukuran profesionalisme adalah kompetensi, efisiensi dan efektifitas serta bertanggung jawab.

\section{Pengembangan Hipotesis}

Penelitian ini mengacu pada beberapa penelitian sebelumnya yang memiliki hubungan dan persamaan variabel serta beberapa keterkaitan lainnya. Penelitian yang dimaksud yaitu penelitian yang dilakukan oleh 
Bertovic, et al. (2002) yang menjelaskan teknik pengimplemenntasian manajemen aset secara bertahap melalui optimalisasi pemanfaatan asset. Dalam studi ini dilakukan di Negaranegara Eropa dengan hasil penelitian bahwa di Negara yang menjadi sampel penelitian (Kroasia dan New-Zealand) telah memiliki departemen khusus untuk pengelolaan asset daerah sehingga telah dapat dioptimalkan pemanfaatan asset daerahnya. Hal tersebut juga telah menunjukkan profesionalisme pengelolaan asset daerah, sehingga hasil penelitiannya dapat disimpulkan optimalisasi pemanfaatan asset dan profesionalisme pengelolaan asset mempengaruhi pendapatan daerah.

Agustina (2005) dalam Widayanti (2010) melakukan suatu studi kasus yang dilakukan di Kabupaten Pontianak tentang manajemen aset Pemerintah Daerah. Hasil penelitian menunjukkan bahwa identifikasi atas asset daerah yang belum dimanfaatkan oleh Pemerintah Daerah menjadi sumber pendapatan asli daerah dan meningkatkan pelayanan publik (public service). Dalam penelitian ini dapat disimpulkan bahwa optimalisasi pemanfaatan asset dapat mempengaruhi pendapatan asli daerah.
Wardhana (2005) meneliti mengenai bagaimana mengelola aset Kota Jakarta. Penelitian ini membahas mengenai keberadaan potensi kota sebagai aset yang dimiliki/dikuasai Pemerintah Provinsi DKI Jakarta. Hasil penelitian menunjukkan bahwa perlu adanya restruktisasi organisasi dalam pengelolaan aset sehingga optimalisasi pemanfaatan asset daerah dapat menjadi lebih professional melalui pembentukan Badan Pengelola dan Dewan Supervisi Aset.

Widayanti (2010) menyatakan bahwa optimalisasi pemanfaatan asset daerah berpengaruh terhadap inventarisasi dan identifikasi asset. Hal tersebut berarti bahwa optimalisasi pemanfaatan asset memiliki potensi peningkatan pendapatan daerah dengan melakukan inventarisasi dan identifikasi dengan menggunakan sistem yang baik.

Pengelolaan (manajemen) aset daerah merupakan salah satu faktor penentu kinerja usaha yang sehat. Manajemen Aset yang didalamnya terkandung optimalisasi pemanfaatan asset merupakan suatu sarana yang efektif untuk meningkatkan kinerja sehingga transparansi kerja dalam pengelolaan aset sangat terjamin tanpa perlu adanya kekhawatiran 
Dewi, Saputra, Prayudi - Optimalisasi Pemanfaatan dan Profesionalisme Pengelolaan ...

akan pengawasan dan pengendalian yang lemah (Siregar, 2004).

Berdasarkan beberapa penelitian terdahulu diatas, maka dapat dirumuskan hipotesis dalam penelitian ini adalah:

H1. Optimalisasi pemanfaatan aset desa berpengaruh terhadap peningkatan pendapatan asli desa

H2. Profesionalisme pengelolaan asset desa berpengaruh terhadap peningkatan pendapatan asli desa

H3. Optimalisasi pemanfaatan asset dan profesionalisme pengelolaan asset secara simultan berpengaruh terhadap peningkatan pendapatan asli desa

\section{METODE}

Rancangan Penelitian

Populasi penelitian ini adalah seluruh desa yang menerima dana desa sesuai UU No. 6 Tahun 2014 tentang Desa di Kabupaten Buleleng. Teknik pengambilan sampel menggunakan purposive sampling dengan kriteria tertentu yaitu perangkat desa yang bersentuhan langsung dengan pengelolaan aset desa. Desain penelitian yang digunakan dalam penelitian ini adalah metode survei. Desain penelitian survei yaitu setiap kantor kepala desa didatangi secara langsung dan diberikan kuesioner. Jumlah desa yang memenuhi kriteria sampel yang berpartisipasi dalam penelitian ini sebanyak 129 Desa (Bulelengkab.go.id diakses 3 Oktober 2016). Dari sejumlah 129 kuesioner yang disebarkan, kuesioner yang kembali berjumlah 87 paket (response rate $=67,4 \%)$. Secara demografis, responden terdiri dari Kepala Desa sejumlah 67 orang dan Sekretaris desa sejumlah 20 orang, mayoritas responden berjenis kelamin laki-laki $(88,5 \%)$, dan sebagian besar berusia $40-49$ tahun $(56,3 \%)$.

\section{Populasi dan Sampel}

Populasi dari penelitian ini adalah Desa yang menerima Dana Desa Se-Kabupaten Buleleng yang terdiri dari 9 (sembilan) kecamatan, yaitu kecamatan Tejakula, Kubutambahan, Sawan, Buleleng, Sukasada, Banjar, Busungbiu, Gerokgak dan Seririt, dimana jumlah Desa yang menerima Dana Desa di Kabupaten Buleleng sampai saat ini adalah berjumlah 129 Desa yang tersebar diseluruh Kecamatan. Responden dari penelitian ini adalah Kepala Desa dan Sekretaris Desa sebagai pihak-pihak yang bersentuhan langsung dengan hal-hal terkait pengelolaan aset desa. Alasan pemilihan sampel ini adalah untuk spesifikasi penelitian yang dilakukan sehingga memudahkan dalam melakukan evaluasi pengelolaan keuangan Desa secara parsial. 
Metode Pengumpulan Data

Data primer dalam penelitian ini adalah data yang diperoleh dan dikumpulkan langsung dari lokasi penelitian melalui kuesioner yang diberikan kepada responden, sementara kuesioner yang digunakan bersumber dari kajian terdahulu dan pembuatan kuesioner dengan modifikasi melalui teori dan regulasi yang berlaku, serta disesuaikan dengan kebutuhan dari objek penelitian dan indikator yang telah teruji validitas dan reliabilitasnya. Dalam penelitian ini, peneliti mengharapkan responden yang akan menjawab kuesioner yang diberikan adalah orang-orang yang mengetahui mengenai lingkup pengelolaan asset desa sebagai bagian dari pendapatan asli desa yaitu Kepala Desa.

\section{Definisi Operasional Variabel}

Optimalisasi Pemanfaatan Aset Desa

Subambang (2004) dalam Widayanti (2010) menjelaskan bahwa kinerja pengelolaan aset daerah merupakan salah satu elemen penting yang menjadi landasan bagi penilaian kinerja keuangan pemerintah daerah, yang menjadi ukuran mengenai kepatutan daerah untuk mendapatkan pinjaman atau berhak untuk menerbitkan obligasi. Bloomquist dan Oldach (2005) menjelaskan bahwa optimalisasi aset di dunia industri adalah proses memaksimalkan nilai aset produksi suatu perusahaan melalui manajemen resiko yang efektif. Variabel optimalisasi pemanfaatan asset desa ini diukur menggunakan instrument penelitian dari Widayanti (2010) dengan berbagai modifikasi pertanyaan kuesioner. Jumlah pernyataan kuesioner berjumlah 15 pernyataan dengan menggunakan skala likert 5 .

Profesionalisme Pengelolaan Aset Desa

Hasil penelitian Riyanto (2014) menyatakan bahwa profesionalisme Birokrasi berpengaruh secara signifikan terhadap Kinerja Aparatur Pemerintah. Hal ini berarti dengan adanya profesionalisme maka dapat meningkatkan kinerja aparatur yang berimplikasi pada pendapatan asli desa. Penelitian lainnya berdasarkan kesamaan variabel yaitu dari hasil penelitian dari Zainal (2012) yang menyatakan bahwa pengelolaan asset daerah berpengaruh signifikan terhadap kinerja pemerintahan daerah yang dilihat dari peningkatan pendapatan asli daerah. Berdasarkan hasil penelitian terdahulu, maka variabel ini dapat diukur menggunakan instrument penelitian dari penelitian Krisindarto (2012) 
Dewi, Saputra, Prayudi - Optimalisasi Pemanfaatan dan Profesionalisme Pengelolaan ...

yang dilakukan berdasarkan siklus profesionalisme pengelolaan asset. Berdasarkan Peraturan Pemerintah Nomor 43 Tahun 2014 tentang peraturan pelaksanaan Undangundang Nomor 6 Tahun 2014 pasal 108 yaitu perencanaan, pengadaan, penggunaan, pemanfaatan, pengamanan, pemeliharaan, penghapusan, pemindahtanganan, penatausahaan, pelaporan, penilaian, pembinaan, serta pengawasan dan pengendalian.

Pendapatan Asli Desa

Pengelolaan keuangan daerah tidak hanya mengoptimalkan pada potensi pajak dan retribusi saja, namun dapat dari pengelolaan aset daerah yang efektif dan efisien. Strategi optimalisasi pengelolaan aset daerah serta kontribusi aset daerah terhadap PAD guna melaksanakan tugas penyelenggaraan pemerintahan yang diharapkan dapat meningkatkan PAD (Nurina, 2014). Penelitian yang berkaitan dengan pendapatan asli desa masih sangat sedikit, sehingga peneliti mengasumsikan pendapatan asli desa sama dengan pendapan asli daerah. Kuesioner penelitian tentang pendapatan asli desa diambil dari teori atau prinsip-prinsip yang terkandung dalam Undang-undang Nomor 6 tahun 2014 tentang Desa yang berisikan tentang pos-pos pendapatan asli desa yaitu hasil usaha desa, hasil pengelolaan kekayaan desa, hasil swadaya dan partisipasi, hasil gotong royong dan lain-lain pendapatan asli desa yang sah.

\section{Teknik Analisis Data}

Sebelum dilakukan analisis data, maka dilakukan uji terhadap instrument yaitu uji validitas dan reliabilitas serta uji asumsi klasik uji multikolinearitas, uji heteroskedastisitas dan uji normalitas. Sedangkan, untuk menguji hubungan antara variabel optimalisasi pemanfaatan asset dan profesionalisme pengelolaan aset terhadap peningkatan pendapatan asli desa menggunakan regresi linier berganda dengan model OLS dengan menggunakan software SPSS for Windows Realesed 17.0 Programe. Metode ini merupakan salah satu cara perhitungan koefisien regresi statistik yang tidak bias, efisiensi dan konsistensi. Metode ini dapat diformulasikan dalam rumus regresi linear berganda sebagai berikut:

$\mathrm{PAD}=\beta_{0}+\beta_{1}$ OPS $+\beta_{2} \mathrm{PPA}+\mathrm{e} \ldots \ldots \ldots \ldots$. (1)

Keterangan:

$\mathrm{PAD}=$ Pendapatan Asli Desa

OPS $=$ Optimalisasi Pemanfaatan Aset 
PPA = Profesionalisme Pengelolaan Aset

e $\quad=$ Error

Untuk menguji koefisien regresi secara parsial antara variabel bebas terhadap variabel terikat dengan tingkat signifikansi $5 \%(\mathrm{a}=$ 0,05) digunakan uji $t$ dangan rumusan hipotesis sebagai berikut:

$\mathrm{H}_{0}: \quad \mathrm{b}_{0}=0$, artinya variabel bebas secara parsial tidak punya pengaruh siginifikan terhadap variabel terikat $\mathrm{H}_{1}$ : $\quad \mathrm{b}_{1} \neq 0$, artinya variabel bebas secara parsial mempunyai pengaruh yang signifikan terhadap variabel terikat

Pengujian koefisien regresi secara simultan dapat dilakukan dengan membandingkan nilai $F$ hitung dan F tabel:

- Jika nilai $\mathrm{F}$ hitung $>\mathrm{F}$ tabel maka variabel bebas (X) berpengaruh terhadap variabel terikat (Y).

- Jika nilai $\mathrm{F}$ hitung < $\mathrm{F}$ tabel maka variabel bebas (X) tidak berpengaruh terhadap variabel terikat (Y).
Berdasarkan nilai signifikansi hasil output SPSS:

- Jika nilai Sig. < 0,05 maka variabel bebas (X) berpengaruh signifikan terhadap variabel terikat $(\mathrm{Y})$.

- Jika nilai Sig. > 0,05 maka variabel bebas (X) tidak berpengaruh signifikan terhadap variabel terikat $(\mathrm{Y})$.

\section{HASIL DAN PEMBAHASAN}

Statistika Deskriptif

Tabel 1. menyajikan hasil analisis statistika deskriptif variabelvariabel yang dioperasionalisasikan pada penelitian ini. Secara umum, tingkat optimalisasi pemanfaatan aset, kadar profesionalisme pengelolaan aset dan besaran pendapatan asli desa pada desa-desa yang menjadi lokasi penelitian tergolong tinggi, masing-masing dengan mean 3,1526 (SD=0,813); $3,4862 \quad(\mathrm{SD}=0,736) ; \quad$ dan 3,3985 $(\mathrm{SD}=0,785)$.

Tabel 1. Statistika Deskriptif Variabel Penelitian

\begin{tabular}{|c|c|c|c|c|c|c|}
\hline \multirow[t]{2}{*}{ Variabel } & \multicolumn{2}{|c|}{$\begin{array}{l}\text { Rentang } \\
\text { Teoretis }\end{array}$} & \multicolumn{2}{|c|}{$\begin{array}{l}\text { Rentang } \\
\text { Aktual }\end{array}$} & \multirow[t]{2}{*}{ Mean } & \multirow{2}{*}{$\begin{array}{l}\text { Std. } \\
\text { Deviation }\end{array}$} \\
\hline & Min & Maks & Min & Maks & & \\
\hline $\begin{array}{l}\text { Optimalisasi Pemanfaatan } \\
\text { Aset }\end{array}$ & 1,00 & 5,00 & 1,20 & 5,00 & 3,1526 & 0,81388 \\
\hline $\begin{array}{l}\text { Profesionalisme } \\
\text { Pengelolaan Aset }\end{array}$ & 1,00 & 5,00 & 1,09 & 4,73 & 3,4862 & 0,73693 \\
\hline Pendapatan Asli Desa & 1,00 & 5,00 & 1,20 & 5,00 & 3,3985 & 0,78559 \\
\hline
\end{tabular}


Dewi, Saputra, Prayudi - Optimalisasi Pemanfaatan dan Profesionalisme Pengelolaan ...

Reliabilitas dan Validitas

Berdasarkan hasil uji

reliabilitas (Tabel 2), variabel optimalisasi pemanfaatan aset desa memiliki nilai Cronbach's Alpha sebesar 0,774 lebih besar dari 0,60. Hal ini berati item-item kuesioner untuk mengukur variabel optimalisasi pemanfaatan aset desa dapat dikatakan konsisten atau reliabel sebagai alat ukur. Hasil uji reliabilitas variabel professionalisme pengelolaan aset desa memberikan nilai Cronbach's Alpha sebesar 0,719 lebih besar dari 0,60. Hal ini berati itemitem kuesioner untuk mengukur variabel profesionalisme pengelolaan aset desa juga dapat dikatakan konsisten atau reliabel sebagai alat ukur. Terakhir, hasil uji reliabilitas atas variabel pendapatan asli desa menghasilkan nilai Cronbach's Alpha sebesar 0,661 lebih besar dari 0,60. Hal ini berati item-item kuesioner untuk mengukur pendapatan asli desa dapat dikatakan konsisten atau reliabel sebagai alat ukur.

Tabel 2. Hasil Pengujian Reliabilitas

\begin{tabular}{lc}
\hline Variabel Penelitian & Cronbach's Alpha \\
\hline Optimalisasi Pemanfaatan Aset & 0,774 \\
Profesionalisme Pengelolaan Aset & 0,719 \\
Pendapatan Asli Desa & 0,661 \\
\hline
\end{tabular}

Sumber: Output SPSS

Sementara itu, hasil pengujian uji validitas untuk variabel optimalisasi pemanfaatan aset desa dapat dipaparkan bahwa dari 11 item pertanyaan memiliki nilai correlated item-total correlation lebih besar dari 0,3 dan signifikan pada level signifikansi $<0,05$. Hal ini berarti indikator yang digunakan untuk mengukur variabel optimalisasi pemanfaatan aset desa dapat dikatakan valid sebagai alat ukur. Kedua, hasil pengujian uji validitas untuk variabel profesionalisme pengelolaan aset desa dapat dipaparkan bahwa dari 10 item pertanyaan memiliki nilai correlated item-total correlation lebih besar dari 0,3 dan signifikan pada level signifikansi $<0,05$. Hal ini berarti indikator yang digunakan untuk mengukur variabel profesionalisme pengelolaan aset desa dapat dikatakan valid sebagai alat ukur. Terakhir, hasil pengujian uji validitas untuk variabel pendapatan asli desa dapat dipaparkan bahwa dari 6 item pertanyaan memiliki nilai correlated item-total correlation lebih besar dari 0,3 dan signifikan pada 
level signifikansi $<0,05$. Hal ini berarti indikator yang digunakan untuk mengukur variabel pendapatan asli desa dapat dikatakan valid sebagai alat ukur.

\section{Uji Asumsi Klasik}

Uji Multikolinieritas

Hasil uji multikolonearitas menunjukkan nilai Tolerance masing-masing variabel lebih besar dari $10 \%$ atau 0,1 yaitu variabel optimalisasi pemanfaatan aset desa sebesar 0,982 dan variabel profesionalisme pengelolaan aset desa sebesar 0,982. Demikian juga dengan VIF masing-masing variabel memiliki nilai yang lebih kecil dari 10 yaitu untuk variabel optimalisasi pemanfaatan aset desa sebesar 1,019 dan variabel profesionalisme pengelolaan aset desa sebesar 1,019. Hasil tersebut dapat disimpulkan bahwa tidak terjadi hubungan atau gejala multikolinieritas antar variabel bebas.

Uji Autokorelasi

Hasil uji autokorelasi pada penelitian ini menggunakan uji Durbin-Watson (DW) dan menghasilkan nilai DW = 2,141 (Tabel 7). Keputusan apakah model regresi menunjukkan gejala autokorelasi/ tidak ditentukan dengan membandingkan nilai DW hitung dengan nilai DU pada tabel Durbin Watson. Pada tabel Durbin-Watson, nilai DU untuk jumlah kasus (n) 87 dan jumlah variabel independen (k) 2 adalah 1,6999. Ketiadaan autokorelasi terpenuhi ketika DW hitung lebih besar daripada DU dan lebih kecil daripada nilai (4 - DU). Dengan memperhatikan nilai DW hitung sebesar 2,141, maka nilai ini terbukti lebih besar daripada DU $(1,6999)$ dan lebih kecil daripada nilai (4 - DU; 4 - 1,699; 2,3001). Dengan demikian dapat dinyatakan model regresi bebas autokorelasi.

\section{Uji Heterokedastisitas}

Uji heterokedastisitas bertujuan menguji apakah dalam model regresi terjadi ketidaksamaan variance dari residual satu pengamatan ke pengamatan lainnya (Ghozali, 2011). Penelitian ini mengaplikasikan uji Glejser untuk meregresikan absolute residual terhadap variabel independen. Keputusan ada/tidaknya gejala heterokedastisitas pada model regresi ditentukan dari nilai signifikansi pengaruh masing-masing variabel independen terhadap variabel absolute residual (AbsUT), yaitu tidak terjadi heterokedastisitas ketika pengaruh variabel indenden tidak signifikan. Hasi pengujian pada tabel 8 menunjukkan nilai signifikansi 
Dewi, Saputra, Prayudi - Optimalisasi Pemanfaatan dan Profesionalisme Pengelolaan ...

lebih dari 0,05 $(\mathrm{OPA}=0,147$ dan PPA $=0,198)$ sehingga dapat dinyatakan bahwa model regresi yang dirumuskan tidak mengandung gejala heterokedastisitas.

Uji Normalitas

Hasil uji normalitas dalam penelitian ini menggunakan uji Kolmogorov-Smirnov Test disajikan pada Tabel 9. Kolmogiorov-Smirnov menunjukkan bahwa nilai Asymp. Sig. (2-tailed) sebesar 0,510 yang lebih besar dari 0,05. Berdasarkan kriteria uji normalitas, data berdistribusi normal jika nilai Asymp. Sig. (2-tailed) lebih besar dari 0,05. Hal ini menunjukkan bahwa sebaran data berdistribusi normal.

\section{Pengujian Hipotesis}

$$
\text { Pengujian hipotesis dilakukan }
$$
dengan menentukan koefisien determinasi, regresi linier berganda, uji kelayakan model $t$ dan uji kelayakan model f. Pertama uji koefisien determinasi digunakan untuk mengetahui besaran dalam persen pengaruh variabel independen secara keseluruhan terhadap variabel dependen. Nilai $\mathrm{R}^{2}$ yang kecil berarti kemampuan variabel-variabel independen dalam menjelaskan variasi variabel dependen dengan sangat terbatas. Berdasarkan hasil uji determinasi diketahui bahwa nilai Adjusted $R$ Square sebesar 0,323, yang mengandung arti bahwa 32\% variasi besarnya Reduksi Kualitas Audit bisa dijelaskan oleh variasi variabel independen yaitu optimalisasi pemanfaatan aset desa dan profesionalisme pengelolaan aset desa. Sedangkan sisanya $68 \%$ dijelaskan oleh variabel lain diluar model. Analisis regresi linier berganda bertujan untuk mengetahui pengaruh optimalisasi pemanfaatan asset desa dan profesionalisme pengelolaan aset desa terhadap pendapatan asli desa pada desa yang berada di Kabupaten Buleleng, Bali. Analisis regresi linear berganda dapat disajikan pada tabel 3.

Berdasarkan hasil analisis diatas, dapat diketahui konstanta (a) $=5,204$, nilai koefisien regresi $\mathrm{b} 1=$ 0,214 dan nilai koefisien b2 $=0,233$. Berdasarkan hasil tersebut dapat ditentukan persamaan regresi linier berganda pola pengaruh variabel optimalisasi pemanfaatan aset desa (X1), profesionalisme pengelolaan aset desa (X2) terhadap pendapatan asli desa (Y) dapat dinyatakan dengan persamaan sebagai berikut:

$$
\begin{aligned}
& \mathrm{Y}=\mathrm{a}+\mathrm{b} 1 \mathrm{X} 1+\mathrm{b} 2 \mathrm{X} 2+\mathrm{e} . \\
& \mathrm{Y}=5.204+0,214 \mathrm{X} 1+0,233 \mathrm{X} 2+\mathrm{e} .
\end{aligned}
$$


Tabel 3. Hasil Analisis Regresi Linier Bergandaa

\begin{tabular}{|c|c|c|c|c|c|c|c|}
\hline \multirow{2}{*}{ Model } & \multicolumn{2}{|c|}{$\begin{array}{l}\text { Unstandardized } \\
\text { Coefficients }\end{array}$} & \multirow{2}{*}{$\begin{array}{c}\begin{array}{c}\text { Standardized } \\
\text { Coefficients }\end{array} \\
\text { Beta }\end{array}$} & \multirow{2}{*}{$\mathrm{t}$} & \multirow{2}{*}{ Sig. } & \multicolumn{2}{|c|}{$\begin{array}{l}\text { Collinierity } \\
\text { Statistics }\end{array}$} \\
\hline & B & $\begin{array}{l}\text { Std. } \\
\text { Error }\end{array}$ & & & & Tolerance & VIF \\
\hline (Constant) & 5,204 & 2,511 & & 2,073 & 0,041 & & \\
\hline OPA & 0,214 & 0,043 & 0,455 & 5,024 & 0,000 & 0,982 & 1,019 \\
\hline PPA & 0,233 & 0,052 & 0,408 & 4,504 & 0,000 & 0,982 & 1,019 \\
\hline
\end{tabular}

a. Dependent Variable: pendapatan Asli Desa

Keterangan: OPA = Optimalisasi Pemanfaatan Aset Desa; PPA = Profesionalisme Pengelolaan Aset Desa

Sumber: Output SPSS

\section{Koefisien regresi Optimalisasi} Pemanfaatan Aset Desa (X1) sebesar 0,214 menggambarkan bahwa Optimalisasi Pemanfaatan Aset Desa mempunyai pengaruh positif terhadap besarnya Pendapatan Asli Desa artinya apabila aparatur desa melakukan Optimalisasi Pemanfaatan Aset Desa maka dapat meningkatkan Pendapatan Asli Desa. Koefisien regresi profesionalisme pengelolaan aset desa (X2) sebesar 0,233 menggambarkan bahwa Profesionalisme Pengelolaan Aset Desa mempunyai pengaruh positif terhadap besarnya Pendapatan Asli desa artinya apabila aparatur desa memiliki Profesionalisme Pengelolaan Aset Desa yang tinggi maka akan dapat meningkatkan pendapatan asli desa. Hal ini mengartikan bahwa terdapat pengaruh positif antara Optimalisasi Pemanfaatan Aset Desa (X1), Profesionalisme Pengelolaan Aset Desa (X2) terhadap Pendapatan Asli Desa (Y).
Hasil uji $t$ (parsial) didapatkan hasil yang pertama: pengaruh optimalisasi pemanfaatan aset desa terhadap pendapatan asli desa, diperoleh nilai t-hitung sebesar 5,024 > dari nilai t-tabel sebesar 1,677 dan nilai signifikan Optimalisasi Pemanfaatan Aset Desa sebesar 0,000 < dari 0,05 sehingga H1 diterima. Hal ini menunjukkan bahwa variabel Optimalisasi Pemanfaatan Aset Desa berpengaruh positif dan signifikan terhadap pendapatan asli desa. Kedua, pengaruh profesionalisme pengelolaan aset desa terhadap pendapatan asli desa, diperoleh nilai t-hitung sebesar 4,504 > dari nilai ttabel sebesar 1,677. Nilai signifikan Profesionalisme Pengelolaan Aset Desa sebesar 0,000 < dari 0,05 sehingga H2 diterima. Hal ini menunjukkan bahwa variabel profesionalisme pengelolaan aset desa berpengaruh positif dan signifikan terhadap pendapatan asli desa. Hasil uji $\mathrm{F}$ didapatkan nilai signifikan 
Dewi, Saputra, Prayudi - Optimalisasi Pemanfaatan dan Profesionalisme Pengelolaan ...

0,00<0,05 sehingga H3 diterima, hal ini menunjukkan variabel independen optimalisasi pemanfaatan aset desa dan profesionalisme pengelolaan aset desa secara simultan berpengaruh terhadap pendapatan asli desa.

\section{Pembahasan}

Pengaruh Optimalisasi Pemanfaatan Aset Desa terhadap Pendapatan Asli Desa

Variabel optimalisasi pemanfaatan aset (X1) memiliki nilai t-hitung sebesar 5,024 > dari nilai ttabel sebesar 1,677 dengan signifikansi sebesar $0,00<0,05$. Sehingga dapat dikatakan bahwa optimalisasi pemanfaatan aset desa berpengaruh positif dan signifikan terhadap pendapatan asli desa. Hasil penelitian ini didukung oleh hasil penelitian yang dilakukan oleh Widayanti (2010) melakukan suatu studi kasus di Kabupaten Pontianak dengan hasil penelitian menyatakan bahwa optimalisasi pemanfaatan asset daerah berpengaruh terhadap inventarisasi dan identifikasi asset. Hal tersebut berarti bahwa optimalisasi pemanfaatan asset memiliki potensi peningkatan pendapatan asli daerah.

Dari indikator yang digunakan untuk mengukur pengaruh optimalisasi pemanfaatan aset semua memiliki pengaruh positif. Indikator yang ada yaitu inventarisasi aset, identifikasi aset, legal audit, penilaian aset, dan optimalisasi asetnya. Desa sudah melakukan optimalisasi pemanfaatan aset sesuai dengan ketentuan yang akan menambah pendapatan asli desa itu sendiri.

Pengaruh Profesionalisme Pengelolaan Aset Desa terhadap pendapatan Asli Desa

Pengaruh profesionalisme pengelolaan aset desa terhadap pendapatan asli desa, diperoleh nilai t-hitung sebesar 4,504 > dari nilai ttabel sebesar 1,677. Nilai signifikan Profesionalisme Pengelolaan Aset Desa sebesar 0,000 < dari 0,05, hal ini menunjukkan bahwa variabel profesionalisme pengelolaan aset desa berpengaruh positif dan signifikan terhadap pendapatan asli desa. Hasil penelitian ini didukung oleh hasil penelitian yang dilakukan oleh Zainal (2012) yang menyatakan bahwa profesionalisme pengelolaan asset daerah berpengaruh signifikan terhadap kinerja pemerintahan daerah yang dilihat dari peningkatan pendapatan asli daerah. Selain itu hasil penelitian ini juga didukung oleh Riyanto (2014) menyatakan bahwa profesionalisme Birokrasi berpengaruh secara signifikan terhadap Kinerja Aparatur Pemerintah. Hal ini berarti dengan 
adanya profesionalisme maka dapat meningkatkan kinerja aparatur yang berimplikasi pada pendapatan asli desa.

$$
\text { Indikator yang digunakan }
$$

untuk mengukur pengaruh profesionalisme pengelolaan aset desa yaitu perencanaan aset, pengadaan aset, penggunaan dan pemanfaatan aset, pengamanan aset, pemeliharaan aset, penghapusan aset yang dimiliki, pemindahtanganan aset, penatausahaan aset, pelaporan dan penilaian aset, pengawasan dan pengendalian aset desa. Indikatorindikator ini memberikan pengaruh positif terhadap pendapatan asli desa, sehingga profesionalisme pengelolaan aset desa berpengaruh positif terhadap pendapatan asli desa.

\section{Pengaruh Optimalisasi Pemanfaatan} Aset Desa dan Profesionalisme Pengelolaan Aset desa terhadap Pendapatan Asli Desa

$$
\text { Variabel independen }
$$

optimalisasi pemanfaatan aset desa dan profesionalisme pengelolaan aset desa secara simultan berpengaruh terhadap pendapatan asli desa, hasil uji $F$ didapatkan nilai signifikan 0,00<0,05 sehingga H3 diterima.

\section{KESIMPULAN, IMPLIKASI DAN KETERBATASAN PENELITIAN}

Penelitian ini secara umum bertujuan untuk untuk menginvestigasi pengaruh optimalisasi pemanfaatan aset desa dan profesionalisme pengelolaan aset desa terhadap peningkatan pendapatan asli desa. Hasil penelitian menunjukkan bahwa upaya-upaya optimalisasi dan profesionalisme pengelolaan aset desa secara signifikan berpengaruh positif terhadap peningkatan pendapatan asli desa, baik secara parsial maupun simultan. Penelitian ini nantinya diharapkan mempunyai manfaat bagi pihak yang berkepentingan. Manfaat penelitian pertama adalah manfaat teoretis yaitu penelitian ini diharapkan dapat memberikan tambahan pengetahuan dan referensi tentang optimalisasi pemanfaatan aset desa dan profesionalisme pengelolaan aset desa, yang memengaruhi peningkatan hasil pendapatan asli desa sehingga hasil ini nantinya dapat digunakan sebagai acuan bagi penelitian berikutnya. Manfaat kedua adalah manfaat praktis penelitian ini diharapakan dapat memberikan kontribusi konkrit bagi pemerintah desa dalam meningkatkan penadapatan asli desa di desa-desa khususnya yang berada di kawasan Kabupaten Buleleng. 
Dewi, Saputra, Prayudi - Optimalisasi Pemanfaatan dan Profesionalisme Pengelolaan ...

\begin{abstract}
Penelitian ini memiliki keterbatasan dalam hal pengoperasionalan variabel karena hanya mempertimbangkan dua faktor utama, yaitu optimalisasi pemanfaatan aset dan profesionalisme pengelolaan aset, sebagai anteseden peningkatan pendapatan asli desa. Pemilihan dua faktor utama ini secara riil didasarkan pada pertimbangan kesesuaian variabel dengan kasuskasus yang terjadi pada lokasi penelitian dan berdasarkan hasil penelitian memang terbukti berpengaruh positif terhadap peningkatan pendapatan asli desa. Penelitian selanjutnya dapat mengoperasionalkan faktor lain yang juga berpotensi memiliki peran terhadap pendapatan asli desa. Selain itu, penggunaan kuesioner rentan terhadap bias-bias respon sehingga perlu dilakukan peningkatan kualitas metodologi penelitian, misalnya melalui kombinasi desain penelitian survei dan wawancara terstruktur.
\end{abstract}

\section{REFERENSI}

Astuti, Indri. (2015). Pengelolaan Pendapatan Asli Desa (Studi Kasus di Desa Ngombakan Kecamatan Polokarto Kabupaten Sukoharjo Tahun 2014). Skripsi. Universitas Muhamadiyah Surakarta.

Bertovic, Hrugo; Kaganova, Olga; Rutledge, John. (2002). Asset
Management Model for Local Governments, Local Government Reform Project (LGRP). The Urban Institute.

Bali Post. 2015.

Bloomquisht, Rob, dan Jim Oldach. (2005). Optimizing Plant Assets, through Improved Reliability Practices. The Journal Orbit, Vol 25 No.1, halaman 31- 37.

Ghozali, Imam. (2011). Aplikasi Analisis Multivariate dengan Prgram IBM SPSS 19. Semaranag: Badan Penerbit Universitas Diponegoro.

Harian Jogja. 2016. Dewa Bejo Tolak Pembentukan BUMDesa. HarianJogja.com, Sabtu 10 September 2016

Krisindarto, Agung. (2012). Pengelolaan Aset Tanah Milik Pemerintah Kota Semarang. Jurnal Pembangunan Wilayah dan Kota, Volume 8 Nomor 4, Halaman 403-411.

Nurina, Devi Listya. (2014). Strategi Optimalisasi Pengelolaan Aset Daerah Untuk Meningkatkan Pendapatan Asli Daerah (Studi Pada Badan Pengelola Keuangan Dan Aset Daerah Kota Batu). Jurnal Administrasi Publik. Volume 2. Nomor 11, Universitas Brawijaya.

Peraturan Menteri Dalam Negeri No.1 Tahun 2016 tentang Pengelolaan Aset Desa

Riyanto, Andi. (2014). Pengaruh Profesionalisme Birokrasi Dan Motivasi Terhadap Kinerja Aparatur Pemerintah Pada Dinas Pendapatan, Pengelolaan Keuangan Dan Aset Daerah Kota Sukabumi. Seminar Nasional Inovasi dan Tren (SNIT) 2014. 
Sedarmayanti. (2013). Manajemen Sumber Daya Manusia: Reformasi Birokrasi dan Manajemen Pegawai Negeri Sipil. Bandung: Refika Aditama.

Siregar, Doli. D. (2004). Management Aset Strategi Penataan Konsep Pembangunan Berkelanjutan secara Nasional dalam Konteks Kepala Daerah sebagai CEO's pada Era Globalisasi dan Otonomi Daerah. PT Gramedia Pustaka Utama, Jakarta.

Undang-undang Republik Indonesia No. 6 Tahun 2014 tentang Desa

Wardhana.I.H. (2005). Mengelola Aset Kota Jakarta. Jurnal Kajian Pengembangan Perkotaan, Vol 01, No. 01, April, halaman 7-10.

Widayanti, Endang. (2010). Pengaruh Manajemen Aset Terhadap Optimalisasasi Pemanfataan Aset Tetap Pemerintah Daerah (Studi Kasus di Kabupaten Sragen). Tesis, Universitas Sebelas Maret Surakarta.

Zainal, Nur Iswahyudi. (2012). Pengaruh Pengelolaan Aset Daerah Terhadap Laporan Keuangan Dinas Pendapatan Pengelolaan Keuangan dan aset Daerah Kabupaten Bone Bolango. Skripsi, Universitas Negeri Gorontalo. 